Ivan L. Milanković

Faculty of Engineering

University of Kragujevac

Nikola V. Mijailović

Faculty of Engineering

University of Kragujevac

Aleksandar S. Peulić

Faculty of Engineering University of Kragujevac

Dalibor Nikolić

Research and Development Center for Bioengineering BiolRC

Igor Končar

Clinical Center Serbia, Belgrade

Themis Exarchos

University of Ioannina, Ioannina

Greece

Oberdan Parodi

National Research Council Pisa

Italy

Nenad D. Filipović

Faculty of Engineering University of Kragujevac

\section{Software and Hardware Systems for Abdominal Aortic Aneurysm Mechanical Properties Investigation}

The main goal of this paper is to describe two different systems that were developed for the purpose of abdominal aortic aneurysm mechanical properties investigation and to present the results of the measurements. The first system is based on the "Bubble Inflated" method and it increases the pressure of physiological saline which affects blood vessel tissue and causes mechanical deformation. The system provides recording the data about the current value of the pressure in the physiological saline by using the appropriate pressure sensor. The second system makes stretches of the vessel tissue in uni-axial direction and save the data about the force and the elongation. Both of these systems use cameras for assessment of the deformation. Obtained results from both systems are used for numerical simulation of computer model for abdominal aortic aneurysm. It gives a new avenue for application of software and hardware systems for determination of vascular tissue properties in the clinical practice.

Keywords: Abdominal aortic aneurysm, bubble inflated method, uni-axial stretch, pressure sensor, force sensor

\section{INTRODUCTION}

The aorta is the largest artery in the human body. It is a blood vessel that carries oxygenated blood away from the heart. It originates just after the aortic valve connected to the left side of the heart and extends through the entire chest and abdomen. The portion of the aorta that lies deep inside the abdomen, right in front of the spine is called the abdominal aorta.

Over time, artery walls may become weak and widen. The pressure of blood pumping through the aorta may then cause this weak area to bulge outward, like a balloon (called an aneurysm). Abdominal aortic aneurysm is localized displacement of the abdominal aorta that is $50 \%$ larger than the proximal normal segment at healthy subject.

Abdominal aortic aneurysm is a disease which exhibit as a localized enlargement of aorta [1]. This enlargement is induced by progressively decrease in the elasticity of the wall of abdominal aorta due to acute inflammation. The degradation of aorta tissue does not include complete aorta, but only intermediate layer which became weaker and susceptible by stress produced by aorta wall. The aneurysm is usually in the form of the bulge produced by the blood pumped under heart pressure. An aneurysm on the wall may contain deposits of cholesterol, calcium, or small blood clots [2].

It is very useful to expose part of the vessel, removed during surgery, to in vitro measurements of

Received: June 2014, Accepted: March 2015

Correspondence to: Ivan L. Milanković

Fakultet inženjerskih nauka Univerziteta u Kragujevcu,

Sestre Janjić br. 6, 34000 Kragujevac, Serbia

E-mail: ivan.milankovic@kg.ac.rs

doi:10.5937/fmet1502161M

(C) Faculty of Mechanical Engineering, Belgrade. All rights reserved mechanical parameters such as modulus of elasticity, Poison's ratio, shear and bulk module. These data can be included into the health information system along with other data, and it can be used as a parameter for evaluating the condition of the vessel after surgery, thereby possibly providing information on the speed of recovery or any complications in the future. Alternatively, these data can be used for purely scientific research purposes.

There are a number of methods used for determining the mechanical parameters of tissue some of which utilize blood vessel tissue stretching in one direction and record the force and elongation [3], [4], [5] with others involving stretching it in two directions, the so-called biaxial stretching of tissue [6], [7] as well as tissue inflation [8]. The very promising technique is based on the ultrasound imaging combined with simultaneous measurement of pressure [9]. In this paper the systems for mechanical properties investigation are presented. The systems consist of two main kind of test based on the one-axial stretch and bubble inflated method based on the radial stretching tissue specimen equally in all direction.

\section{MATERIALS AND METHODS}

\subsection{Bubble inflated method}

Knowing of the biomechanical properties of blood vessel tissues has increasing importance for better understanding mechanism of cardiovascular diseases, established medical diagnosis and treatment process.

One of the very interesting techniques, based on inflation of a circular membrane of some material to determine the mechanical properties, is known as "bubble inflated" method or bulge test. This method is 
used for the determination of characteristics of rubber for making elastic tires, with compressed air used as a working fluid [10]. This method has been refined over the years in terms of the technique, applications and mathematical formulae that were involved. As a result, it is still popular in the biomechanical tissue investigation [11].

A piece of material is fixed on the circular hole on its edge. The boundary of material is nailed by bolts and other part of material can perform free movement. Upper side is exposure by air pressure and lower side is connected by fluid installation which produces pressure and deformed tissue to outward as it is shown in Figure 1. If we suppose isotropic material behavior the formed structure have spherical shape due to elasticity of material.

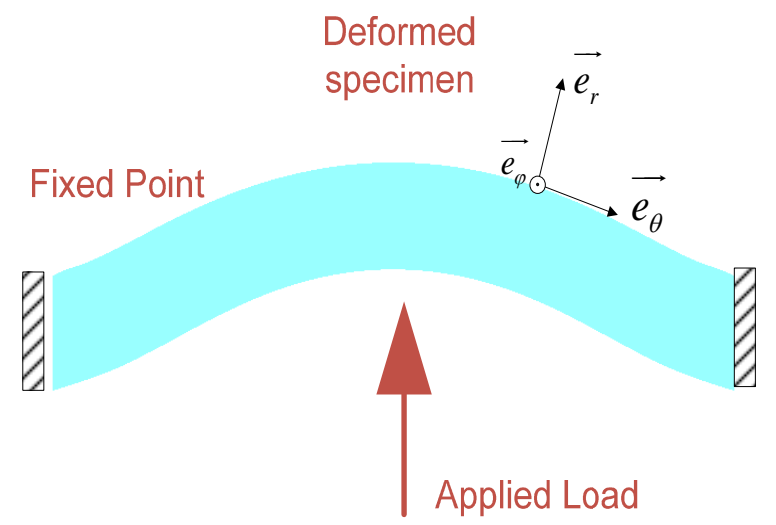

Figure 1. Bubble inflated method

In this way, as a result of inflation, we can show an example of biaxial strain on the top of the sphere and plane strain on the edge, so that the Cauchy stress tensor has the following reduced form:

$$
\sigma=\left[\begin{array}{ccc}
\sigma_{r r} & 0 & 0 \\
0 & \sigma_{\theta \theta} & 0 \\
0 & 0 & \sigma_{\theta \theta}
\end{array}\right]
$$

The relationship between the thickness of the sample, $e$, the pressure difference inside and outside the sample, $\mathrm{P}$, and the radius of curvature, $R$, is given in the following equation:

$$
\sigma_{\theta \theta}=\frac{P \cdot R}{2 e}
$$

During the experiment, the pressure, i.e. the pressure difference, can be obtained by using a corresponding sensor, while the radius of the curvature can be determined by measuring the top view of deformation, so that it is possible to determine the thickness of the tissue. If we assume that the thickness is uniform, both before and after inflation, and using the equation of conservation of volume of the sample, we have the following relation:

$$
E=\frac{P}{1-\left(l / l_{0}\right)^{2}}=\frac{P}{1-\frac{e}{e_{0}}}
$$

In this equation (3), E is Young's modulus, $e_{0}$ presents the initial sample thickness and $l_{0}$ and $l$ present curve lengths at the initial point and at the point when the tissue thickness is equal to $e$, respectively.

\subsection{One axial stretch}

For the elastic material the Navier linear elastic equation is satisfied:

$$
\begin{aligned}
& \mu \nabla^{2} \mathbf{u}(x, y, z) \\
& +(\lambda+\mu) \nabla(\nabla \cdot \mathbf{u}(x, y, z)) \\
& +\mathbf{f}(x, y, z)=0
\end{aligned}
$$

where $\mathbf{u}(\mathrm{x}, \mathrm{y}, \mathrm{z})$ is displacement vector, $\mathbf{f}(\mathrm{x}, \mathrm{y}, \mathrm{x})$ is external force acting by the volume unit of deformed body. The parameters $\lambda$ and $\mu$ are Lamé's elasticity constants which describe the behavior of the elastic body.

These constants can be represented by Young's modulus E and Poisson's ratio $v$ using expressions:

$$
\mu=\frac{E}{2(1+v)}
$$

$$
\lambda=\frac{E v}{(1+v)(1-2 v)}
$$

Main goal of mechanical property investigation is determination of elastic parameter according to measurement of applied forces and displacement and deformation of tissue specimen. In numerical simulation the two methods are common used. The first method uses pre described displacement and varying material properties to obtain desired applied external stress and forces. The second approach is based on assigning measured value of pressure or force and varying the material properties to obtain measured value of displacement.

For one-axial stress tension the Cauchy strain tensor has a form:

$$
\varepsilon=\left[\begin{array}{ccc}
\frac{\sigma_{x x}}{E} & 0 & 0 \\
0 & -\frac{\sigma_{x x}}{E} v & 0 \\
0 & 0 & -\frac{\sigma_{x x}}{E} v
\end{array}\right]
$$

For one axial stretch the value of Young's modulus is given by relation:

$$
E=\frac{\sigma_{X X}}{\varepsilon_{x X}}
$$

where $\sigma_{\mathrm{xx}}$ is applied one axial stress by the initial cross section and $\varepsilon_{\mathrm{xx}}$ is corresponding axis strain. 


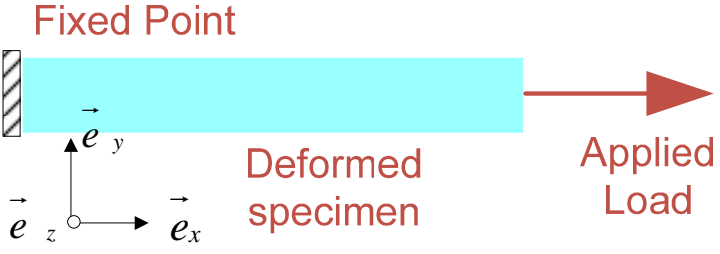

Figure 2. One axial stretch

The process of the one axial stretch is shown in the Figure 2. The specimen is attached and fixed by the one side and other is moveable and exposed by the applied tensile force.

\section{EXPERIMENTAL SETUP}

The system for determination of blood vessel tissue biomechanical parameters using the "Bubble Inflated" method includes a pump, heater, heat exchanger, pressure sensor, camera, and control unit.

The pump, heater, heat exchanger and pressure sensor allow fine settings the current value of the pressure of physiological saline which acts on blood vessel tissue and providing the appropriate temperature to the physiological saline and simulate real physiological conditions. The pump adjusts the pressure of the physiological saline, and the pressure sensor provides information about its value. The sensor is supplied with a voltage 12-36 VDC, and outputs a current of 4-20 mA, which reflects the change in pressure of the physiological saline. A heater is used to heat the distilled water in order to adjust the temperature of the physiological saline to $37^{\circ} \mathrm{C}$, regardless of their physical mixing, since heating the physiological saline in the heater is not allowed in order to prevent chemical reactions that could alter the composition of the physiological saline [12].

The camera has the task of monitoring the deformations of the tissue specimen while the pressure of the physiological saline acting by the upside on the tissue. According to very small velocity of deformation and pressure increasing the sampling frequency of $1 \mathrm{fps}$ (frames per second) is quite satisfactory. The camera provide an image resolution of $1000 \times 1000$ pixels at 96 dpi (dots per inch). This resolution is enough for measurement a space resolution of $0.25 \mathrm{~mm}$. According to [13] this system resolution can be enhanced using supper resolution algorithms,

The control unit is responsible for synchronization of the entire system, and enables communication with the computer via the USB interface in order to design graphical changes in the pressure of the physiological saline in real-time, as well as displaying images from the camera output. Taking into account the described functionality, the hardware for the control unit was designed as presented in Figure. 3.

The central part of this scheme presents the microcontroller unit U1. When selecting which microcontroller is going to be used, it has to be taken into account that this part must be capable to enable the USB communication, A/D conversion, and to provide the sufficient number of input and output pins. As a solution, the Microchip PIC18F4550 microcontroller is selected. Therefore, communication between the control unit and computer was achieved using the USB interface, and the conversion of analogue signals from the output of the pressure sensor to digital values was performed using the $\mathrm{A} / \mathrm{D}$ converter that is built-in into the microcontroller. Since the pressure sensor has a current output of 4-20 mA, and the A/D input should be in the range of $0-5 \mathrm{~V}$, there is, in parallel with the output of the sensors, a resistor of $250 \Omega$ connected, so that the input for the A/D converter voltage is in the range of 1$5 \mathrm{~V}$, which reflects the changes in pressure of physiological saline. In a situation where the input for the $\mathrm{A} / \mathrm{D}$ converter voltage was less than $1 \mathrm{~V}$, that would indicate that there had been a failure. This configuration of sensor and $\mathrm{A} / \mathrm{D}$ converter ensure the measurement of pressure in system by the resolution of $0.1 \mathrm{KPa}$.

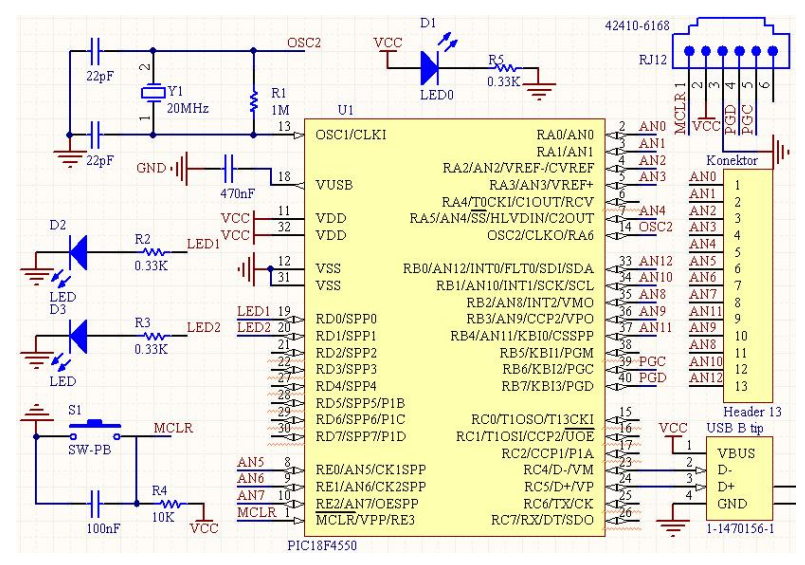

Figure. 3 - Scheme of control- acquisition unit

As stated above, the computer communicates with the system via the USB interface. There was an application that collects data of the physiological saline pressure changes and drew a graph in real-time, as well as displaying images from the camera output. This application also creates a text file which includes data about measured pressure, as well as a folder in which all of the images were stored. This enables the flow of the whole experiment to be shown later, for demonstration purposes.

The system which makes stretches of the vessel tissue in the uni-axial direction includes one stepper motor, force sensor, amplifier and control-acquisition unit which main task is to control the stepper motor and save the data about the force and the elongation. The stepper motor stretches the tissue in the uni-axial direction and force sensor detects the force which acts on the tissue. The output signal or the force sensor is really low and it needs to be amplified. For that purpose, the amplifier is used and the amplified signal is sent to the control-acquisition unit. The configuration of the control-acquisition unit is same as the controlacquisition unit used for the system for determination of blood vessel tissue biomechanical parameters using the "Bubble Inflated" method. The main difference is that the control-acquisition unit used for the system which makes stretches of the vessel tissue has a part which controls the stepper motor.

At the beginning of the experiment for determination of blood vessel tissue biomechanical parameters using 
the "Bubble Inflated" method the initial condition of temperature of physiological saline need to be satisfied. The blood vessel tissue specimen needs to be set up in a suitable container and nailed by the screws to prevent the physiological saline from leaking during the pressure increase. The air was superseded from the system and the temperature of the saline was adjusted to the physiological temperature of $37^{\circ} \mathrm{C}$. the whole system that was developed for this experiment is presented in the Figure 4.

When the initial conditions were satisfied, the experiment could begin. The pressure is gradually increased by the pump. The physiological saline interacts on the tissue which is deformed. The control unit, with a pressure sensor, records the pressure and a webcam performs video acquisition of the deformed tissue.

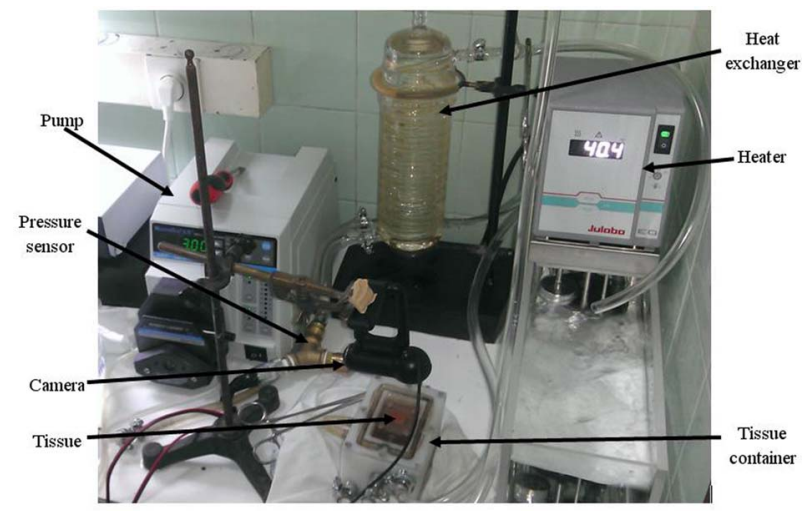

Figure. 4 - Architecture of the system designed for the experiment

The software application for showing, archiving pressure values and the corresponding video data in real-time is developed in the $\mathrm{C \#}$ programing language. Figure 5 shows the sample window of the acquisition software with corresponding image and pressure value.

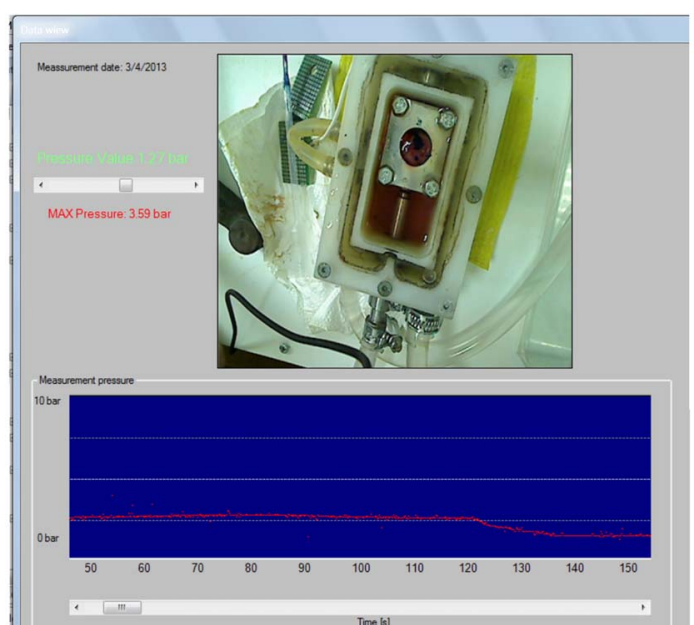

Figure. 5 - Appearance of the window with simultaneous display of images of tissue and pressure in real-time

\section{RESULTS AND DISCUSSION}

The pressure change during the experiment is shown in the Figure. 6. The pressure increases approximately linearly by the average growth rate of the $2.08 \mathrm{KPa} / \mathrm{s}$.
These changes provide relatively slow deformation changes and reduce some nonlinearity and viscous elastic behavior.

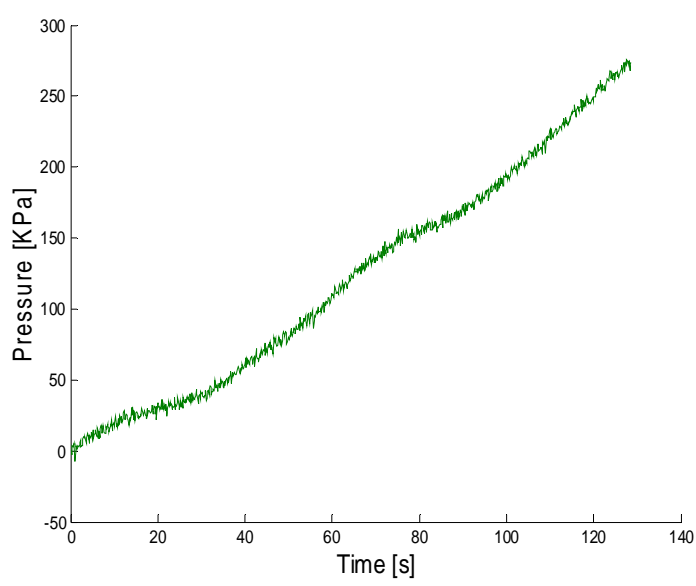

Figure. 6 - The pressure value during the tissue inflation

Figure. 7 shows the deformed tissue specimen with the marked black area and corresponding segmented region.

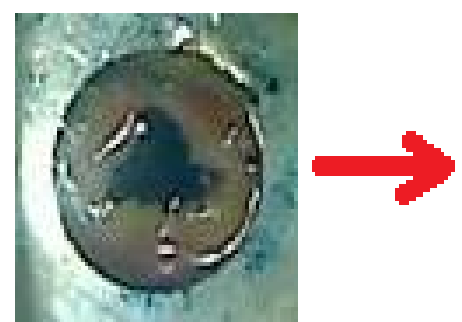

a.)

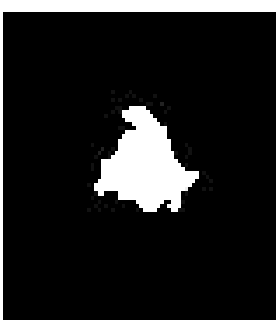

b.)
Figure. 7 - a.) The deformed tissue specimen b.) the segmented marked area

The tissue was marked with black waterproof paint, and the ratio of this black area was calculated using the appropriate image processing technique to determine the vertical displacement. This area ratio depends on the deformation value and the view angle of the camera.

For area ratio determination the original RGB image is necessary to convert in the greyscale image. Gray value image is segmented by the growth region algorithms and using empirical threshold value. The extracted marked region is showed in the Figure 7 b.).

This procedure is applied for a number of images captured during experiments. According to the conservation of volume the increasing of area ration is followed by the decreasing of the thickness of the tissue specimen. The mean value of strain is given by relation:

$$
\text { strain }=1-\frac{S_{0}}{S}
$$

where $\mathrm{S}_{0}$ is initial area ration and $\mathrm{S}$ is area ration after deformation in corresponding moment of the experiment. The area value is obtained by the counting the white pixels of the segmented image. The measured pressure values in eight selected points are shown in the 
Table 1. For every measurement point the area ration of initial and current marked region is determined. Using these strains values the Young's modulus in $[\mathrm{MPa}]$ is obtained in specified points.

Table 1. Pressure, strain and Young's modulus for some measurement points

\begin{tabular}{|c|l|l|c|}
\hline $\begin{array}{c}\text { Presure } \\
{[\mathrm{KPa}]}\end{array}$ & $\mathbf{S}_{\mathbf{0}} / \mathbf{S}$ & Strain & E [Mpa] \\
\hline 25 & 0.91 & 0.09 & 0.25 \\
\hline 37 & 0.75 & 0.25 & 0.14 \\
\hline 67 & 0.72 & 0.28 & 0.23 \\
\hline 100 & 0.71 & 0.29 & 0.33 \\
\hline 141 & 0.68 & 0.32 & 0.43 \\
\hline 162 & 0.68 & 0.32 & 0.50 \\
\hline 193 & 0.63 & 0.37 & 0.51 \\
\hline 234 & 0.62 & 0.38 & 0.61 \\
\hline
\end{tabular}

In the Figure 8 is presents correlation between the mean strain and the Young's modulus of the tissue species for a number of experimental points. According to eight characteristic points, we can see that tissue has some nonlinearity dependent Young's modulus of the strain for a small strain value and approximately linear dependent for strain greater than 0.25 .

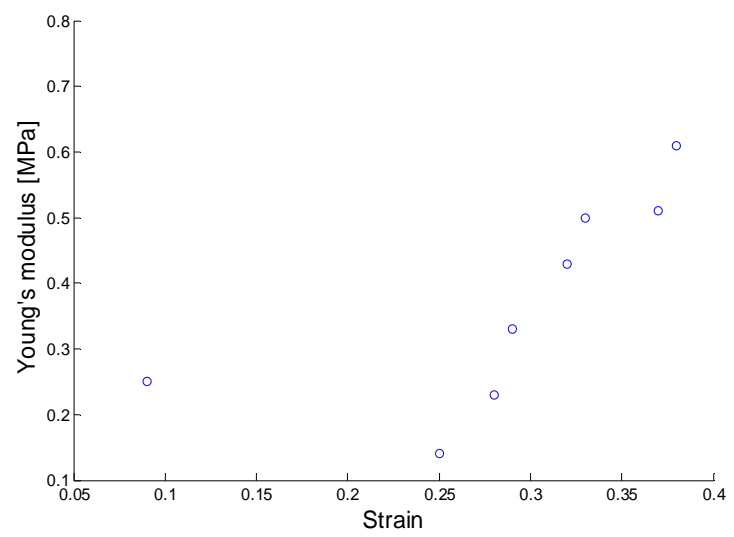

Figure. 8 - Dependent Young's modulus of the strain during experiment

The one axial stretch test is also performed on the tissue specimen of the same patient. In the Figure 9, the tissue specimen is presented.

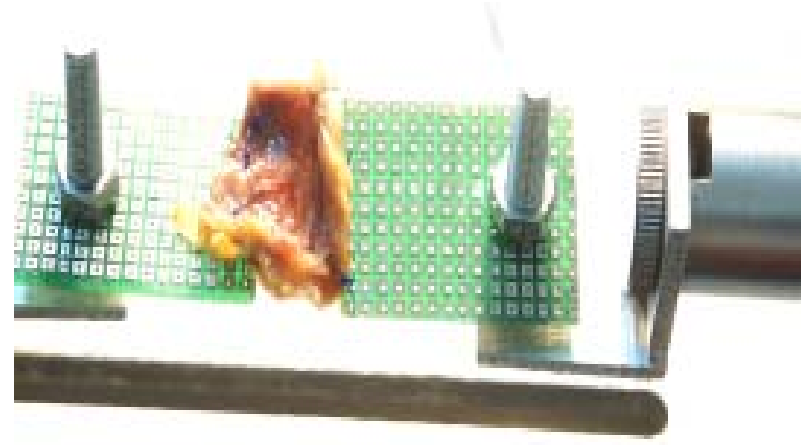

Fig. 9 - One axial stretch of tissue pattern

The stretching force during experiment is shown in the Figure 10. The force reaches maximal value immediately before the tissue rupture. After rupture the force rapidly drops.

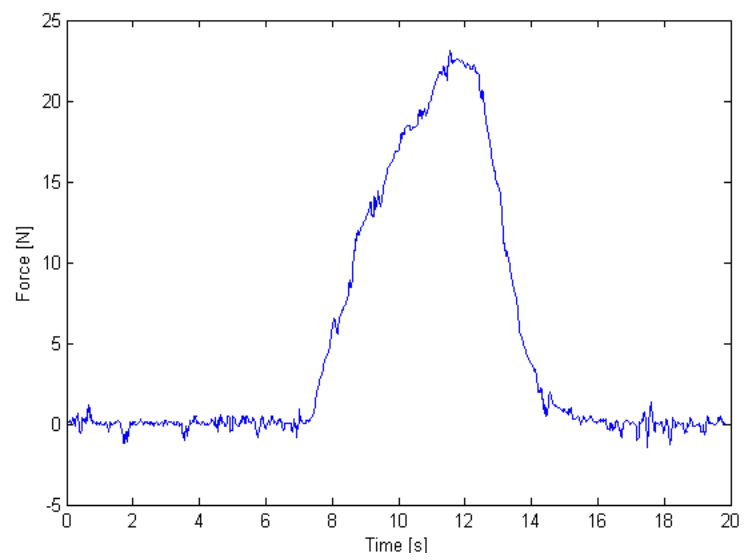

Figure. 10 - The force value measured during one axial stretch

The stretching is performed by the constant speed of the $1 \mathrm{~mm} / \mathrm{s}$. The strain can be obtained directly integrating this speed during time.

The Young's modulus during time is given by relation:

$$
E(t)=\frac{F(t) \cdot L_{0}}{A_{0} \cdot v \cdot t}
$$

where $F(t)$ is measured force, $A_{0}$ is the area of cross section, $v$ is stretching speed and $t$ is amount of time.

The Young's modulus value using measurement force and given stretching speed from the moment when force rise up to rupture of tissue is shown on the Figure 11 .

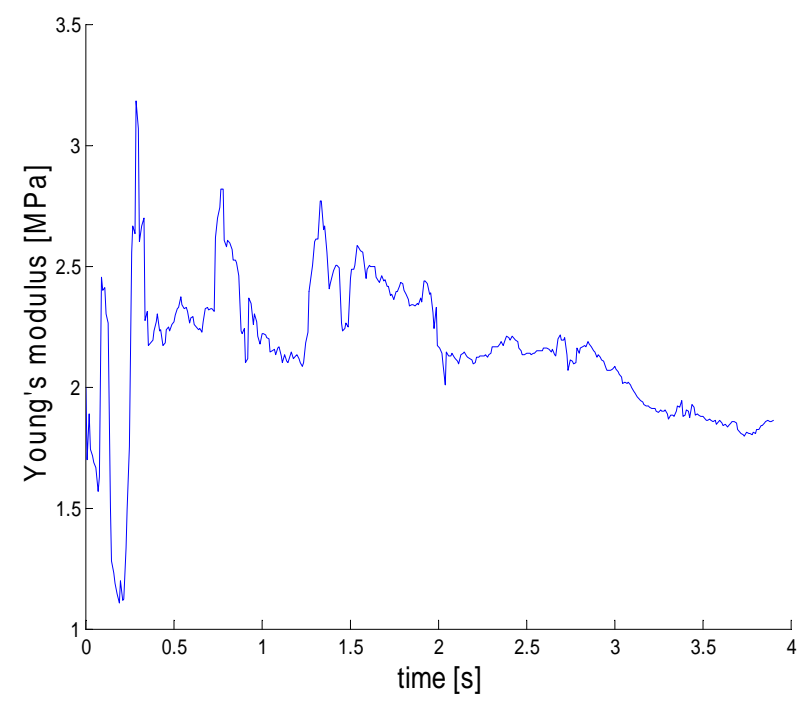

Figure. 11 - Young's modules change during stretching time

The calculated Young's modulus can be used as parameter in the numerical simulation of cardio vasculature system.

Shear stress obtained by the finite element software PAK is shown in the Figure 12.

The shear stress distribution is calculated when the pressure on the vessels wall is around $15 \mathrm{KPa}(120$ $\mathrm{mmHg}$ ) and according to [14] Poisson's ratio is assumed to be 0.38 


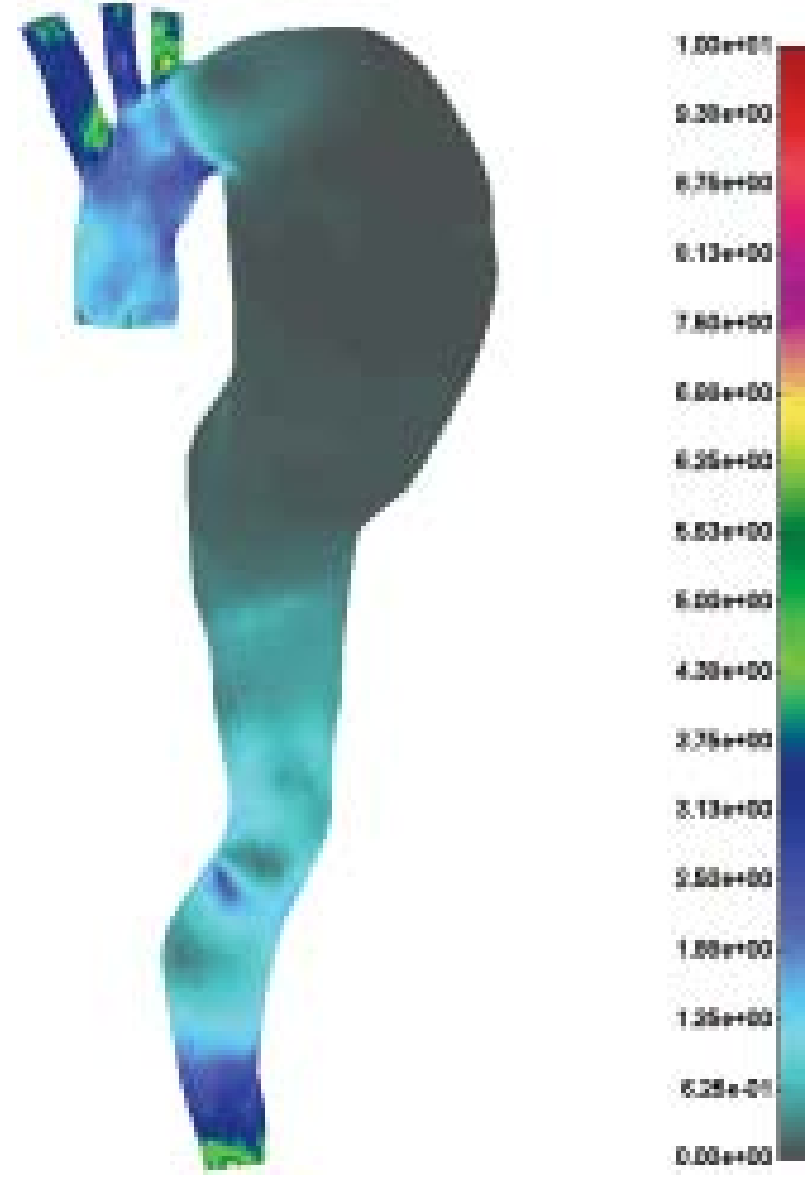

Figure. 12 - Shear stress distribution of aorta wall

\section{CONCLUSION}

In this paper, the development and realization of a system for abdominal aortic aneurysm tissue mechanical properties research using the "Bubble Inflated" method and one-axial stretch is presented. By measuring deformation and pressure values, it is possible to determine Young's modulus of elasticity which, for a specified patient, can be useful in numerical simulation of cardio vasculature system. It was assumed that the blood vessel tissue is isotropic homogeneous media and the problem is spherically symmetrical.

More accurate analysis can be obtained by using a more complex consideration of tissue structure such as presence of fibers segments in the tissue specimen and space variation of Young's modulus, Poisson's ratio and anisotropic behavior; this should be the subject of future research.

\section{ACKNOWLEDGMENT}

This paper was supported by the Ministry of Education Science and Technological Development of the Republic of Serbia (projects) III 41007 and ON 174028.

\section{REFERENCES}

[1] Bickerstaff, Linda K., et al. "Abdominal aortic aneurysms: the changing natural history." Journal of vascular surgery 1.1 (1984): 6-12.
[2] Sakalihasan, Natzi, Raymond Limet, and O. D. Defawe. "Abdominal aortic aneurysm." The Lancet 365.9470 (2005): 1577-1589.

[3] Rice, Kevin M., et al. "Uniaxial stretch-induced regulation of mitogen-activated protein kinase, Akt and p70 S6 kinase in the ageing Fischer $344 \times$ Brown Norway rat aorta." Experimental physiology 92.5 (2007): 963970.

[4] D.P. Sokolis, E.M. Kefaloyannis, M. Kouloukoussa, E. Marinos, H. Boudoulas, P.E. Karayannacos: A structural basis for the aortic stress-strain relation in uniaxial tension, Journal of biomechanics, Vol. 39, No. 9, 2006, pp. $1651-1662$.

[5] G. A. Holzapfel: Determination of material models for arterial walls from uniaxial extension tests and histological structure, Journal of theoretical biology, Vol. 238, No. 2, 2006, pp. 290-302.

[6] John A. Stella, Jun Liao, Michael S. Sacks, Timedependent biaxial mechanical behaviour of the aortic heart valve leaflet, Journal of Biomechanics Volume 40, Issue 14, 2007, Pages 3169-3177.

[7] Billiar, Kristen L., and Michael S. Sacks. "Biaxial mechanical properties of the natural and glutaraldehyde treated aortic valve cusp-part I: experimental results." Journal of biomechanical engineering 122.1 (2000): 2330 .

[8] A.J. Slifkaa, E.S. Drexlera, J.E. Wrighta, R. Shandasb, Bubble-test method for synthetic and bovine vascular material, Journal of Biomechanics, 39:10, 1939-1942 (2006).

[9] Bihari, P., et al. "Strain Measurement of Abdominal Aortic Aneurysm with Real-time 3D Ultrasound Speckle Tracking." European Journal of Vascular and Endovascular Surgery 45.4 (2013): 315-323.

[10] Sasso, M., et al. "Characterization of time-dependent materials by biaxial stretching tests." Proceedings of SEM Annual Conference. Springfield, MA. 2007.

[11] A. Brunona, K. Bruyere-Garniera, M. Coreta, Characterisation of the non-linear behaviour and the failure of human liver capsule through inflation tests, Journal of the Mechanical Behaviour of Biomedical Materials, Volume 4, Issue 8, November 2011, Pages 1572-1581.

[12] Ivan Milanković, Nikola Mijailović, Igor Končar, Dalibor Nikolić, Nenad Filipović, Aleksandar Peulić, "Development of the system for abdominal aortic aneurysm mechanical properties research using "Bubble Inflated" method." Serbian Journal of Electrical Engineering 10.3 (2013): 415-423.

[13] Park, Sung Cheol, Min Kyu Park, and Moon Gi Kang. "Super-resolution image reconstruction: a technical overview." Signal Processing Magazine, IEEE 20.3 (2003): 21-36

[14] HučkoBranislav. "EXPERIMENTAL MEASUREMENT OF ARTERIAL MECHANICAL PROPERTIES." (2009).

\section{СОФТВЕРСКИ И ХАРДВЕРСКИ СИСТЕМИ ЗА ИСПИТИВАЊЕ МЕХАНИЧКИХ \\ КАРАКТЕРИСТИКА АБДОМИНАЛНЕ АОРТЕ ЗАХВАЋЕНЕ АНЕУРИЗМОМ}

Иван Л. Миланковић, Никола В. Мијаиловић, Александар С. Пеулић, Далибор Николић, Игор 


\section{Кончар, Themis Exarchos, Oberdan Parodi, Ненад}

\section{Д. Филиповић}

Главни циљ овог рада јесте да опише два различита система развијена за испитивање механичких карактеристика абдоминалне аорте захваћене анеуризмом и да презентује експерименталне резултате. Први систем је заснован на методи „надувавања мехура“ и он повећава притисак физиолошког раствора који утиче на ткиво крвних судова и изазива механичке деформације. Систем обезбеђује снимање података о тренутној вредности притиска у физиолошком раствору коришћењем одговарајућег сензора притиска. Други систем развлачи ткиво по једној оси и чува податке о сили и елонгацији. Оба система користе камеру за процену деформације. Добијени резултати од оба система се користе за нумеричке симулације компјутерских модела за абдоминалну аорту захваћену анеуризмом. Ови системи дају нову смерницу за примену софтверских и хардверских решења у циљу одређивања карактеристика крвних судова у клиничкој пракси. 